medRxiv preprint doi: https://doi.org/10.1101/2021.03.10.21253255; this version posted March 12, 2021. The copyright holder for this preprint (which was not certified by peer review) is the author/funder, who has granted medRxiv a license to display the preprint in It is made available under a CC-BY 4.0 International license.

\title{
Multicenter, Randomized, Open-Label, Comparative Study of Therapeutic Efficacy, Safety and Tolerability of BNO 1030 application in the technology of delayed prescription of antibiotics in patients with severe acute
} tonsillitis.

V. I. Popovych, I. V. Koshel, O. N. Malofiichuk, L. I. Pyletska, O. A. Semeniuk, O. V. Martynnyk, R. N. Orlovska, O. I. Leta

\begin{abstract}
.
Acute bacterial tonsillitis occurs in 20-30\% of immunocompetent children; however, the frequency of antibacterial drug prescriptions reaches up to $90 \%$. Delayed antibiotic prescription is recommended by current guidelines. The study objective was to determine the efficacy of phytoneering extract BNO 1030 in the technology of delayed antibiotic prescription in patients with severe acute tonsillitis.
\end{abstract}

Methods. In the multicenter, randomized, open-label, comparative study, 182 out of 200 randomized children with acute tonsillitis aged 6-12 years completed the study. Evaluation criteria: a reduced severity of sore throat when swallowing and at rest, throat irritation at rest, hyperemia of the tonsils assessed by a physician according to a 4-point scale at each visit compared to Visit 1, dynamics of self-assessment of general well-being, intensity of sore throat and difficulty swallowing according to a 10-point visual analogue scale, frequency of antibiotic prescriptions, therapeutic benefit from BNO 1030 in days.

Results. The use of phytotherapeutic medicinal product BNO 1030 in addition to the standard symptomatic treatment of severe acute tonsillitis provides a clinically significant, adequate reduction in the symptom severity assessed by a physician at V2 $(p<0.005)$. There are significant differences in the patient's self-assessment of the symptoms from treatment Day 2 ( $\mathrm{p}<0.005)$. This allows to significantly reduce the duration of systemic antipyretic administration ( $<$ 0.005). In the first days of treatment, when a decision on delay of antibiotic prescription is made, a therapeutic benefit in two days in patients of the treatment group was observed compared to the

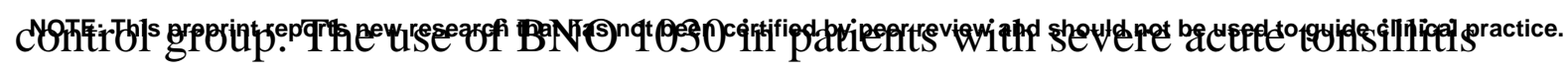


medRxiv preprint doi: https://doi.org/10.1101/2021.03.10.21253255; this version posted March 12, 2021. The copyright holder for this preprint (which was not certified by peer review) is the author/funder, who has granted medRxiv a license to display the preprint in perpetuity.
It is made available under a CC-BY 4.0 International license.

significantly reduces, by $43.7 \%$ or 2.3 times, the need for prescribing antibiotic therapy as part of the technology of delayed antibiotic prescription $(\mathrm{p}<0.005)$. During treatment, no side effects and complications of the disease were recorded.

Conclusion. BNO 1030 is a safe and effective medicinal product for the treatment of severe acute tonsillitis in children aged 6-12 years. It provides a significant therapeutic benefit when administered in addition to standard symptomatic therapy and reduces the irrational antibiotic prescription.

Key words: severe acute tonsillitis, delayed antibiotic therapy, BNO 1030.

Trial registration: ClinicalTrials.gov Identifier: NCT04537819 https://clinicaltrials.gov/ct2/show/NCT04537819?term=ATi-2\&draw=2\&rank=1

\section{Introduction}

Acute tonsillitis (AT) (J03.0-J03.9) is a very common infectious disease characterized by inflammation of the tonsils. It occurs in all age groups but more often at the age of 5-15 years and accounts for about $5 \%$ of all visits to the physician [1]. Most cases are viral. The most common cause is adenovirus and Epstein-Barr virus. Acute bacterial tonsillitis occurs in immunocompetent children in $20-30 \%$ of cases, in adults - in 5-15\%, and its cause is group A beta-hemolytic streptococcus (GABHS) [2]. It should be noted that there are no reliable symptoms of bacterial tonsillitis. To determine the indications for antibiotic therapy, patients are stratified according to the Centor-McIsaac scale. However, even with a high total score (> 3), the probability of detecting GABHS in a smear ranges from $30 \%$ to $50 \%[3,4]$. Thus, antibiotic therapy is not indicated in most AT cases. At the same time, the frequency of prescribing antibacterial drugs in acute tonsillitis ranges from $50 \%$ to $90 \%[5,6]$. Irrational antibiotic prescription in viral tonsillitis, in particular associated with the Epstein-Barr virus, is related to a high incidence of severe, generalized rashes involving limbs [7]. Irrational antibiotic prescription is one of the main causes of the global problem of antibiotic resistance, since inadequate antibiotic 
medRxiv preprint doi: https://doi.org/10.1101/2021.03.10.21253255; this version posted March 12, 2021. The copyright holder for this preprint (which was not certified by peer review) is the author/funder, who has granted medRxiv a license to display the preprint in perpetuity.
It is made available under a CC-BY 4.0 International license .

therapy is prescribed on average in $50 \%$ of cases worldwide according to WHO data $[4,8,9]$.

Delayed antibiotic therapy is one of the strategies to reduce irrational antibiotic prescription in uncomplicated acute respiratory infections [10,11]. Delayed antibiotic prescriptions show almost the same patient satisfaction rate as antibiotic prescription (86\% versus $91 \%$ ). The technology of delayed prescription has reduced the frequency of antibiotic therapy to $31 \%$ and does not lead to an increase in the number of streptococcus-associated complications $[5,6]$.

Expectations of antibiotic prescription are highest in patients with sore throat and fever. Nevertheless, their prescription has practically no effect on these symptoms, if they are not associated with a bacterial infection [12]. According to current recommendations, paracetamol, often in combination with ibuprofen, is successfully used for symptomatic treatment in patients with sore throat and fever $[13,14]$. Several studies have shown that fever inhibits viral replication and has a stimulating effect on the patient's immune system. Therefore, antipyretics may even prolong the duration of infectious diseases [15-19]. In addition, paracetamol has been associated with the risk of some potentially dangerous side effects and unintentional overdose in children [20-22].

In light of the targeted effect on the reduction in the clinical manifestations of tonsillitis, the use of herbal medicinal products could be interesting, since according to studies, phytotherapy for inflammatory diseases of the pharynx is prescribed by $28 \%$ of doctors [23]. The most studied preparations in this respect are Echinacea and Pelargonium sidoides preparations. However, randomized studies have not shown their efficacy in patients with acute tonsillitis [2,24]. In clinical practice, a combination phytoneering aqueous extract of BNO 1030 consisting of seven medicinal herbs is used, namely: Marshmallow root (Radix Althaeae), Cammomile flowers (Flores Chamomillae), Horstail herb (Herba Equiseti), Walnut leaves (Folia Jungladis), Yarrow herb (Herba Millefolii), Oak bark (Cortex Quercus), Dandelion herb (Herba Taraxaci), known as Imupret ${ }^{\circledR}$ (known in some countries as Tonsilgon $\left.{ }^{\circledR} \mathrm{N}\right)$. The components of the drug provide antiviral, antibacterial, anti- 
medRxiv preprint doi: https://doi.org/10.1101/2021.03.10.21253255; this version posted March 12, 2021. The copyright holder for this preprint (which was not certified by peer review) is the author/funder, who has granted medRxiv a license to display the preprint in

It is made available under a CC-BY 4.0 International license .

inflammatory and immunomodulatory effects [25, 26, 27]; indications for use are "treatment of upper respiratory tract diseases (tonsillitis, pharyngitis, laryngitis) and the prevention of complications in viral respiratory infections". Clinical studies in children have shown that the additional use of the phytoneering drug BNO 1030 (Imupret ${ }^{\circledR}$ ) for the treatment of acute tonsillitis significantly reduces the clinical symptoms of tonsillitis, improves the assessment of the patients' general well-being and quality of life, reduces the use of NSAIDs and the overall duration of treatment with no side effects [28, 29]. However, in the scientific literature, there are no reports on efficacy studies of Imupret ${ }^{\circledR}$ with delayed antibiotic prescription in patients with acute rhinosinusitis which comply with GCP standards.

The objective of this study was to evaluate the efficacy of the additional use of phytoneering extract BNO 1030 in the technology of delayed antibiotic prescription in patients with severe acute tonsillitis versus standard symptomatic therapy according to clinical guidelines [2].

\section{Materials and methods}

\subsection{Trial design}

Multicenter, Randomized, Open-Label, Comparative Study of Therapeutic Efficacy, Safety and Tolerability of Imupret application in the technology of delayed prescription of antibiotics in patients with severe acute tonsillitis was conducted in six outpatient institutions in Ukraine from July 2019 to January 2020. The study was conducted in accordance with the GCP standards and the Declaration of Helsinki. In addition, the study was approved by the Ethics Committee at all study sites. The parents of each child gave their written consent to participate in the study.

\subsection{Participants}

210 outpatients were enrolled in this study. 200 outpatients aged 6-12 years diagnosed with acute bacterial tonsillitis were randomized and divided into two groups: the treatment group of patients who received BNO 1030 in addition to standard therapy and the control group of patients who received standard symptomatic therapy. The treatment group $(n=100)$ included $47(47 \%)$ boys and 53 
medRxiv preprint doi: https://doi.org/10.1101/2021.03.10.21253255; this version posted March 12, 2021. The copyright holder for this preprint (which was not certified by peer review) is the author/funder, who has granted medRxiv a license to display the preprint in perpetuity.
It is made available under a CC-BY 4.0 International license.

$(53 \%)$ girls (average age $8.61 \pm 1.994)$, the control group included $43(43 \%)$ boys and $57(57 \%)$ girls (average age $8.51 \pm 1.789)$.

Diagnostic and differential diagnostic criteria for acute tonsillitis were carried out in accordance with the DEGAM recommendations provided in clinical guidelines adopted in Europe and Ukraine [2]. A clinical diagnosis of AT was made based on the presence of such symptoms as sore throat at rest and in swallowing, hyperaemia and swelling with possible plaque on the tonsils, cervical lymphadenitis and fever. The diagnosis of severe acute tonsillitis was made in the case of 4-5 points according to the McIsaac Scale.

\section{Inclusion criteria:}

— Male and female outpatient subjects aged 6-12 years diagnosed with acute tonsillitis

— The possibility to start treatment within 72 hours after the disease symptoms occur; 4-5 points according to the McIsaac Scale

- Willingness and ability of the patient and (or) parents to comply with the requirements of the Study Protocol

- Signed informed consent

\section{Withdrawal criteria:}

- The decision of the patient and/or parents to discontinue participation in the study and withdrawal of written informed consent

- Loss of contact with the patient, individual intolerance to the investigational medicinal product and/or to the reference treatment regimen, the occurrence of serious and/or unforeseen adverse events/reactions in a patient during the study

- Significantly reduced general condition, the development of complications of the underlying disease, which in the physician's opinion require patient's withdrawal from the study

— Patient's violation of the procedures provided by the Protocol

\section{Exclusion criteria:}


medRxiv preprint doi: https://doi.org/10.1101/2021.03.10.21253255; this version posted March 12, 2021. The copyright holder for this preprint (which was not certified by peer review) is the author/funder, who has granted medRxiv a license to display the preprint in perpetuity.
It is made available under a CC-BY 4.0 International license .

- -1 to 3 points according to the McIsaac Scale; indications for immediate initiation of systemic antibiotic therapy

- Suspected infectious mononucleosis (clinically)

- The use of systemic antibacterial or antifungal drugs, systemic glucocorticosteroids, cytostatics in the last 14 days

- Intolerance or increased individual sensitivity to any of the components of the investigational medicinal product and the reference treatment regimen

The patients of two groups were of similar sex, age, clinical manifestations of the disease $(\mathrm{p}<0.05)$.

\subsection{Interventions}

From the time of randomization, patients of two groups have been keeping to a sparing diet; irritating factors (physical and chemical) were eliminated; benzydamine spray 3-4 times a day, paracetamol (if case of pain, hyperthermia). Patients of the treatment group additionally received BNO 1030, drops per os, from one batch in the following dosage strength: children aged 6-11 years - 15 drops 6 times a day; children above 11 years -25 drops 6 times a day.

BNO 1030, drops per os, is a standardized alcoholic aqueous extract. Active substances: $100 \mathrm{~g}$ drops contain $29 \mathrm{~g}$ of an alcoholic aqueous extract (extracting agent: ethanol $59 \%(\mathrm{~V} / \mathrm{V})$ made from the following medicinal plants:

Marshmallow root (Radix Althaeae) $\quad 0.4 \mathrm{~g}$;

Cammomile flowers (Flores Chamomillae) $0.3 \mathrm{~g}$;

Horstail herb (Herba Equiseti) $\quad 0.5 \mathrm{~g}$;

Walnut leaves (Folia Jungladis) $\quad 0.4 \mathrm{~g}$;

Yarrow herb (Herba Millefolii) $\quad 0.4 \mathrm{~g}$;

Oak bark (Cortex Quercus) $\quad 0.2 \mathrm{~g}$;

Dandelion herb (Herba Taraxaci) $\quad 0.4 \mathrm{~g}$;

Excipients: Ethanol $19 \%(\mathrm{~V} / \mathrm{V})$, purified water.

Name and address of the manufacturer: Bionorica SE, Kerschensteinerstrasse, 11 - 15, 92318, Neumarkt, Germany. 
medRxiv preprint doi: https://doi.org/10.1101/2021.03.10.21253255; this version posted March 12, 2021. The copyright holder for this preprint (which was not certified by peer review) is the author/funder, who has granted medRxiv a license to display the preprint in perpetuity

The drug is registered in Ukraine and available over-the-counter (OTC). Therefore, formulation, manufacturing process, packaging and labelling of the drug comply with GMP and current national requirements of Ukraine. A detailed description of all aspects of the quality and safety of BNO 1030 drops is part of the corresponding product characteristics. Approved indications for use are the treatment of upper respiratory tract diseases (tonsillitis, pharyngitis, laryngitis) and the prevention of complications and recurrences in viral respiratory infections.

ENT practitioners with experience of at least 5 years were involved in the study.

\subsection{Outcome measures}

All data were evaluated by a physician at the beginning of the study and at three follow-up visits within 10 days (Table 1).

\section{Schedule of assessments}

\begin{tabular}{|c|c|c|c|c|c|c|c|c|c|}
\hline V1 & & V2 & & V3 & & & & & V4 \\
\hline day 1 & day 2 & day 3 & day 4 & day 5 & day 6 & day 7 & day 8 & day 9 & day 10 \\
\hline
\end{tabular}

Treatment group

Reference treatment + Imupret

Control group

Reference treatment

V1 day 1 Screening, randomization, prescription of treatment

V2 day $3 \pm 1 \quad$ Status evaluation, possible prescription of antibiotics

V3 day $5 \pm 1 \quad$ Evaluation of treatment efficacy, possible prescription of antibiotics (phone contact)

V4 day $10 \pm 1 \quad$ Evaluation of treatment efficacy, end of treatment

The physician evaluated the symptoms included in the scale of local manifestations of tonsillitis: sore throat when swallowing and at rest, throat irritation at rest, hyperaemia of the tonsils. All symptoms were evaluated according to a 4point scale $(0-$ no symptoms, 1 - mild, 2 - moderate, 3 - severe/pronounced $)$. In the diary, the patient daily assessed the general well-being, intensity of sore throat 
medRxiv preprint doi: https://doi.org/10.1101/2021.03.10.21253255; this version posted March 12, 2021. The copyright holder for this preprint (which was not certified by peer review) is the author/funder, who has granted medRxiv a license to display the preprint in perpetuity.
It is made available under a CC-BY 4.0 International license.

and difficulty swallowing according a ten-point visual analogue scale. At Visits 2 and 3 , the physician assessed the patient's condition and made a decision on the need to prescribe the antibiotic therapy.

The key efficacy endpoint was: a reduced severity of each symptom (complaint) included into the scales of tonsillitis manifestations, up to 1 point or less, the absence of indications for antibiotic therapy prescription.

Secondary efficacy endpoints: dynamics in a reduced severity of symptoms of the disease assessed according a point scale at Visits 2, 3 and 4 compared with Visit 1; a decrease in the total score (the sum of points for each symptom) according to the local scale manifestations of tonsillitis at Visits 2, 3 and 4 compared with Visit 1; a decrease in temperature in the armpit at Visits 2 and 3 compared with Visit 1; the patient's self-assessment of the quality of life (daily); duration of NSAID administration.

\subsection{Sample size}

The clinical study has been developed to obtain a reliable description of clinical efficacy of active (additional) use of BNO 1030 compared to the standard treatment only. Depending on findings, several trial descriptive and statistical evaluations were performed so that a biometric estimate of the sample size is not required. However, in order to guarantee a sufficient sample size for data analysis, the sample size $\mathrm{N}=200$ was chosen. Patients were sorted in a 1:1 ratio.

\subsection{Randomization}

The clinical part of the randomized study is open, without a blinding procedure. Subjects are randomized to one of two possible treatments according to the basic randomization list. Randomization was performed using the software [StatSoft is a random number generator]. Randomization was performed for each patient who signed an informed consent.

\subsection{Statistical methods}


medRxiv preprint doi: https://doi.org/10.1101/2021.03.10.21253255; this version posted March 12, 2021. The copyright holder for this preprint (which was not certified by peer review) is the author/funder, who has granted medRxiv a license to display the preprint in perpetuity.
It is made available under a CC-BY 4.0 International license.

In order to analyse homogeneity of groups, descriptive statistics methods were used for description of the baseline condition of the treatment and control group (for quantitative parameters - n, mean arithmetic, median, standard deviation, minimum and maximum values; for qualitative parameters - incidence and share as \%). Verification of normality of data distribution in groups was performed for quantitative parameters using Shapiro-Wilk test. If the data in groups showed normal distribution according to certain parameters, the groups were compared by these parameters using Student's test for independent samples. Otherwise (if the data distribution was different from normal), comparison of groups was performed using Mann-Whitney test. For categorical parameters, the groups were compared using Pearson's chi-squared test or Fisher's exact test.

For analysis of efficacy, descriptive statistics parameters were calculated in each group (n, mean arithmetic, median, standard deviation, minimum and maximum values) for all visits in accordance with patients' examination scheme. Analysis of dynamics of the said parameters in each group was performed using two-way analysis of variance (ANOVA) according to the following scheme: "Visit" factor is fixed (levels: Visit 1... Visit n); "Subjects" factor is random. Results of the subsequent visits were compared against the data of Visit 1 via contrast analysis using simple contrasts. Comparison between groups in dynamics of tested parameters was performed by differences dTi $=($ TVisit $n-T V i s i t ~ 1)$ of assessed parameters using Mann-Whitney test. The level of confidence for Shapiro-Wilk test was accepted equal to 0.01 , and for the rest of the criteria it was accepted equal to 0.05 .

The analysis was performed in software environment IBM SPSS 22.0 
medRxiv preprint doi: https://doi.org/10.1101/2021.03.10.21253255; this version posted March 12, 2021. The copyright holder for this preprint (which was not certified by peer review) is the author/funder, who has granted medRxiv a license to display the preprint in perpetuity.

It is made available under a CC-BY 4.0 International license .

\section{Results}

\subsection{Study sample}

210 patients aged 6-12 years were enrolled in the study (Fig. 1).

\section{Enrollment}

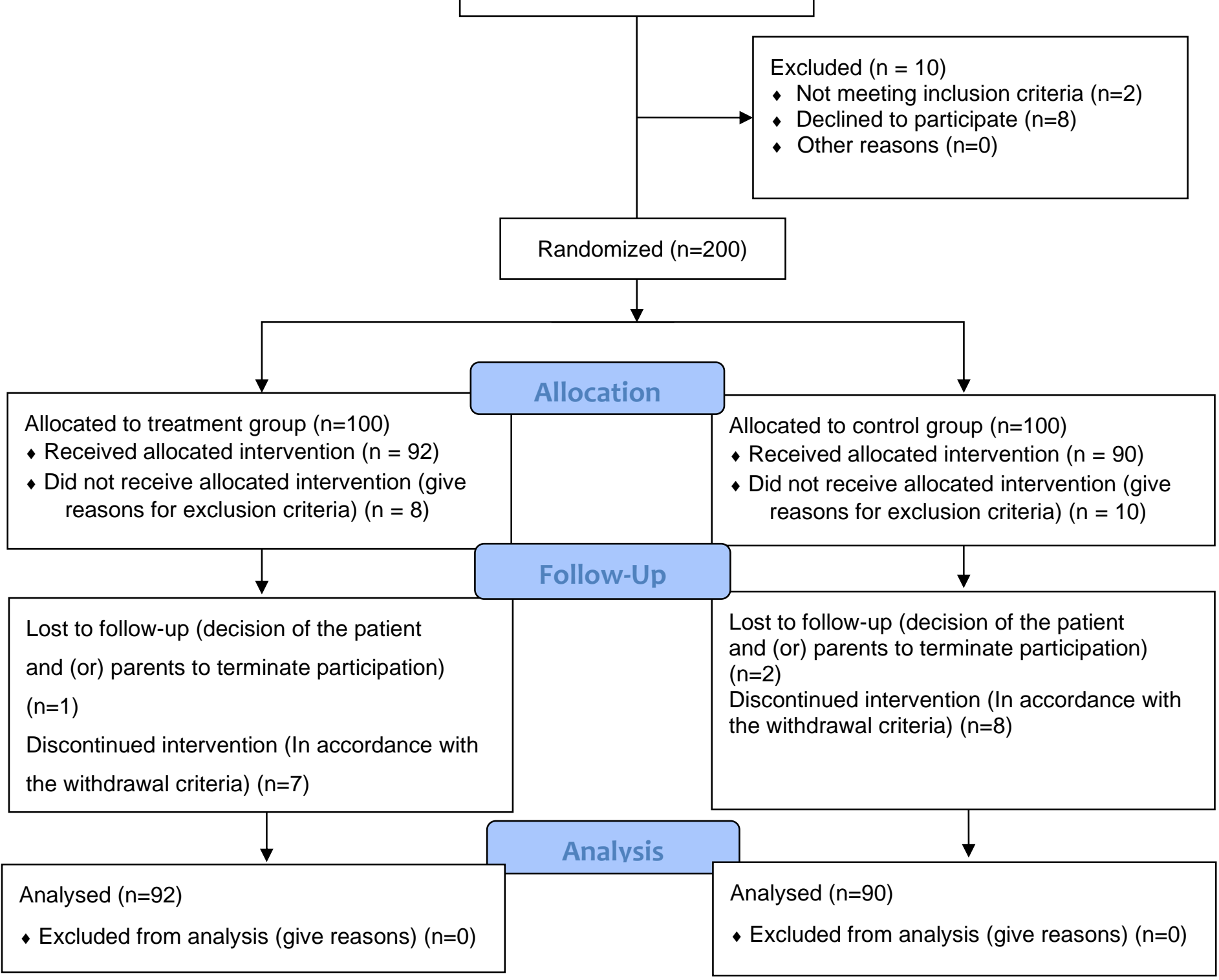

Fig. 1 Patients included in screening, randomization and excluded from the study

Of the 210 patients enrolled, $10(4.7 \%)$ were not included in the study. The reason was non-compliance with the study inclusion criteria: age non-compliance $(n=2)$ and the unwillingness of a patient and/or his/her parents to comply with the 
medRxiv preprint doi: https://doi.org/10.1101/2021.03.10.21253255; this version posted March 12, 2021. The copyright holder for this preprint (which was not certified by peer review) is the author/funder, who has granted medRxiv a license to display the preprint in It is made available under a CC-BY 4.0 International license.

protocol requirements $(n=8)$. The remaining 200 patients were randomized to either the control group $(n=100)$ or the treatment group $(n=100) .18$ patients $(9.0 \%)$ were excluded from the study. The reason was the presence of exclusion criteria (decision to discontinue participation in the study) $(\mathrm{n}=10)$ in the control group and $(\mathrm{n}=8)$ in the treatment group. Thus, from July 2019 to January 2020, 182 (91\%) out of the 200 randomized patients ( $\mathrm{n}=92$ in the treatment group) and ( $\mathrm{n}=90$ in the control group) completed the study and were analysed.

The gender distribution in the groups was as follows: out of 100 patients in the treatment group, 47 (47\%) were boys and $53(53 \%)$ were girls; out of 100 patients in the control group, 43 (43\%) were boys and 57 (57\%) were girls. There were slightly more girls than boys (55\% vs. $45 \%$ ) among patients enrolled in the study. According to the age criterion, the groups were homogeneous: the average age of patients was $8.61 \pm 1.994$ in the treatment group and $8.51 \pm 1.789$ in the control group.

In general, there were no significant differences in demographic characteristics among patients from the treatment and control groups at baseline (Day 1) $(\mathrm{p}<0.05)$.

Table 2 shows the comparative characteristics of the treatment and control groups according to the total score of the tonsillitis severity in points using the McIsaac Scale.

Table 2

\begin{tabular}{|c|c|c|c|c|c|}
\hline \multirow{2}{*}{ Parameter } & \multirow{2}{*}{ Group } & \multicolumn{4}{|c|}{ Statistical indicators } \\
\cline { 3 - 5 } & & $\mathbf{n}$ & $\mathbf{M} \pm$ SD & p-value $\begin{array}{c}\text { Homogeneity of } \\
\text { the groups* }\end{array}$ \\
\hline \multirow{2}{*}{ Mclsaac scale } & Treatment & 100 & $4.45 \pm 0.500$ & \multirow{2}{*}{$\mathrm{P}=0.569$} & Homogeneous \\
\cline { 3 - 4 } & Control & 100 & $\begin{array}{c}4.41 \pm 0.49 \\
4\end{array}$ & \\
\hline
\end{tabular}

$*$ The conclusion is drawn at the significance level of 0.05

All patients had severe tonsillitis since the symptom severity in all patients included in the study was $>4$ points: $4.41 \pm 0.494$ in the control group and $4.45 \pm 0.500$ in the treatment group. There were no differences in the severity of tonsillitis between patients at baseline (Day 1) $(\mathrm{p}<0.05)$.

\subsection{Outcomes and estimation}


medRxiv preprint doi: https://doi.org/10.1101/2021.03.10.21253255; this version posted March 12, 2021. The copyright holder for this preprint (which was not certified by peer review) is the author/funder, who has granted medRxiv a license to display the preprint in

The main clinical manifestation most typical for a patient with acute tonsillitis is a sore throat. Table 3 shows the results of the physician assessment of symptom severity of sore throat when swallowing and at rest, as well as throat irritation in patients of both groups on three follow-up visits.

Table 3

Dynamics of the symptom severity of acute tonsillitis depending on the group.

\begin{tabular}{|c|c|c|c|c|c|c|c|c|c|c|}
\hline \multirow{3}{*}{ 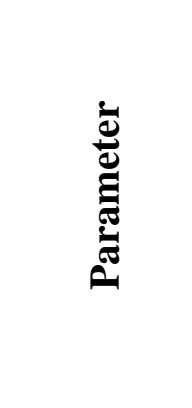 } & \multicolumn{10}{|c|}{ Statistical indicators } \\
\hline & \multirow[b]{2}{*}{$\stackrel{5}{: 5}$} & \multicolumn{3}{|c|}{ Treatment group } & \multicolumn{3}{|c|}{ Control group } & \multicolumn{3}{|c|}{$\begin{array}{c}\text { Comparison } \\
\text { of the groups }\end{array}$} \\
\hline & & $\mathbf{n}$ & $\mathbf{M} \pm \mathbf{S D}$ & 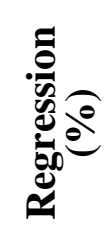 & $\mathbf{n}$ & $\mathbf{M} \pm \mathbf{S D}$ & 矛氙 & dT & 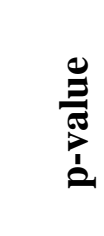 & 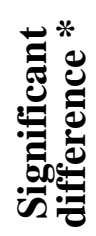 \\
\hline \multirow{3}{*}{$\begin{array}{l}\text { Pain when } \\
\text { swallowing }\end{array}$} & V1 & 100 & $2.69 \pm 0.526$ & - & 100 & $2.59 \pm 0.605$ & - & - & - & - \\
\hline & $\mathrm{V} 2$ & 99 & $1.65 \pm 0.733$ & $3 \overline{8.7}$ & 98 & $2.06 \pm 0.831$ & -20.5 & $\mathrm{dT}_{2}$ & 0.000 & $\underline{\text { Sign }}$ \\
\hline & V4 & 92 & $0.16 \pm 0.532$ & -94.1 & 90 & $0.71 \pm 0.874$ & -72.6 & $\mathrm{dT}_{4}$ & 0.000 & Sign \\
\hline \multirow{3}{*}{$\begin{array}{l}\text { Sore throat } \\
\text { alone }\end{array}$} & V1 & 100 & $2.43 \pm 0.671$ & - & 100 & $2.47 \pm 0.611$ & - & - & - & - \\
\hline & $\mathrm{V} 2$ & 99 & $1.30 \pm 0.788$ & -46.5 & 98 & $1.84 \pm 0.765$ & -25.5 & $\mathrm{dT}_{2}$ & 0.000 & $\underline{\text { Sign }}$ \\
\hline & V4 & 92 & $0.11 \pm 0.425$ & -95.5 & 90 & $0.48 \pm 0.619$ & -80.6 & $\mathrm{dT}_{4}$ & 0.000 & $\underline{\text { Sign }}$ \\
\hline \multirow{3}{*}{$\begin{array}{l}\text { Throat } \\
\text { irritation } \\
\text { alone }\end{array}$} & V1 & 100 & $2.16 \pm 0.813$ & - & 100 & $1.96 \pm 0.844$ & - & - & - & - \\
\hline & V2 & 99 & $1.13 \pm 0.680$ & -47.7 & 98 & $1.52 \pm 0.899$ & -22.4 & $\mathrm{dT}_{2}$ & 0.000 & Sign \\
\hline & V4 & 92 & $0.12 \pm 0.409$ & -94.4 & 90 & $0.47 \pm 0.601$ & -76.0 & $\mathrm{dT}_{4}$ & 0.000 & $\underline{\text { Sign }}$ \\
\hline \multirow{3}{*}{$\begin{array}{l}\text { Redness of } \\
\text { the tonsils }\end{array}$} & V1 & 100 & $2.39 \pm 0.723$ & - & 100 & $2.42 \pm 0.727$ & - & - & - & - \\
\hline & V2 & 99 & $1.41 \pm 0.729$ & -41.0 & 98 & $1.94 \pm 0.895$ & -19.8 & $\mathrm{dT}_{2}$ & 0.000 & Sign \\
\hline & V4 & 92 & $0.33 \pm 0.697$ & -86.2 & 90 & $0.96 \pm 0.947$ & -60.3 & $\mathrm{dT}_{4}$ & 0.000 & $\overline{\text { Sign }}$ \\
\hline
\end{tabular}

At baseline (V1), there were no significant differences in the sore throat pain intensity at rest, pain in swallowing and throat irritation between patients in the treatment and control groups $(\mathrm{p}<0.05)$. Since initially the groups did not differ in assessment of the symptom severity, the individual differences dT2 $=(\mathrm{V} 2-\mathrm{V} 1)$ and $\mathrm{dT} 4=(\mathrm{V} 4-\mathrm{V} 1)$ were calculated for each patient by each parameter. In the course of treatment at V2, the intensity of these symptoms was significantly less pronounced in the treatment group compared to the control group (significant differences, $\mathrm{p}>0.05$ ). Between V2 and V3, there was a further decrease in symptom severity in both groups. Significant differences between the groups were observed even at the end of treatment $(\mathrm{p}>0.05)$. 
medRxiv preprint doi: https://doi.org/10.1101/2021.03.10.21253255; this version posted March 12, 2021. The copyright holder for this preprint (which was not certified by peer review) is the author/funder, who has granted medRxiv a license to display the preprint in

perpetuity.
It is made available under a CC-BY 4.0 International license .

Table 4 shows the results of self-assessment of the condition within 10 days of treatment for three symptoms: general well-being, sore throat and difficulty swallowing (from 0 to 10 points for each symptom).

Table 4

\section{Dynamics of tonsillitis symptoms according to patients' self-assessment}

\begin{tabular}{|c|c|c|c|c|c|c|c|c|c|c|}
\hline \multirow{3}{*}{ 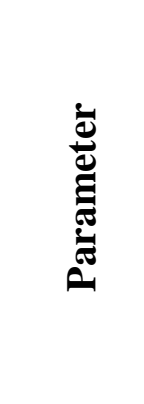 } & \multicolumn{10}{|c|}{ Statistical indicators } \\
\hline & \multirow[b]{2}{*}{ ڤે⿱一𫝀) } & \multicolumn{3}{|c|}{ Treatment group } & \multicolumn{3}{|c|}{ Control group } & \multicolumn{3}{|c|}{$\begin{array}{c}\text { Comparison } \\
\text { of the groups }\end{array}$} \\
\hline & & $\mathbf{n}$ & $\mathbf{M} \pm \mathbf{S D}$ & 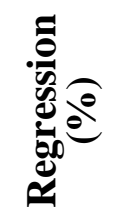 & $\mathbf{n}$ & $\mathbf{M} \pm \mathbf{S D}$ & 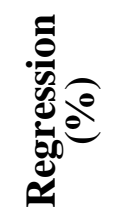 & dT & 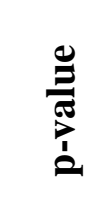 & 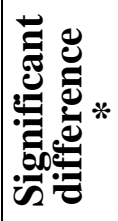 \\
\hline \multirow{10}{*}{$\begin{array}{c}\text { Self- } \\
\text { assess } \\
\text { ment of } \\
\text { well- } \\
\text { being }\end{array}$} & D1 & 100 & $7.23 \pm 1.524$ & - & 100 & $7.10 \pm 1.475$ & - & - & - & - \\
\hline & D2 & 99 & $6.25 \pm 1.710$ & -13.6 & 98 & $6.76 \pm 1.632$ & -4.8 & $\mathrm{dT}_{2}$ & 0.000 & $\underline{\text { Sign }}$ \\
\hline & D3 & 99 & $5.07 \pm 1.797$ & -29.9 & 97 & $6.12 \pm 1.883$ & -13.8 & $\mathrm{dT}_{3}$ & 0.000 & $\underline{\text { Sign }}$ \\
\hline & D4 & 98 & $3.96 \pm 2.056$ & -45.2 & 96 & $5.27 \pm 2.085$ & -25.8 & $\mathrm{dT}_{3}$ & 0.000 & $\underline{\text { Sign }}$ \\
\hline & D5 & 95 & $3.20 \pm 2.061$ & -55.7 & 95 & $4.49 \pm 2.310$ & -36.8 & $\mathrm{dT}_{5}$ & 0.000 & Sign \\
\hline & D6 & 90 & $2.26 \pm 1.696$ & -68.7 & 89 & $4.06 \pm 1.979$ & -42.8 & $\mathrm{dT}_{6}$ & 0.000 & $\underline{\text { Sign }}$ \\
\hline & D7 & 87 & $1.52 \pm 1.593$ & -79.0 & 85 & $3.49 \pm 1.919$ & -50.8 & $\mathrm{dT}_{7}$ & 0.000 & $\underline{\text { Sign }}$ \\
\hline & D8 & 83 & $1.02 \pm 1.370$ & -85.9 & 80 & $2.99 \pm 1.831$ & -57.9 & $\mathrm{dT}_{8}$ & 0.000 & $\underline{\text { Sign }}$ \\
\hline & D9 & 83 & $0.51 \pm 1.086$ & -92.9 & 77 & $2.29 \pm 1.669$ & -67.7 & $\mathrm{dT}_{9}$ & 0.000 & $\underline{\text { Sign }}$ \\
\hline & D10 & 83 & $0.25 \pm 1.948$ & -96.5 & 77 & $1.69 \pm 1.489$ & -76.2 & $\mathrm{dT}_{10}$ & 0.000 & Sign \\
\hline \multirow{10}{*}{$\begin{array}{c}\text { Self } \\
\text { estee } \\
\text { m } \\
\text { sore } \\
\text { throat }\end{array}$} & D1 & 100 & $6.71 \pm 2.006$ & & 100 & $6.77 \pm 1.711$ & & & - & - \\
\hline & D2 & 99 & $5.82 \pm 2.002$ & -13.3 & 98 & $6.41 \pm 1.858$ & -5.3 & $\mathrm{dT}_{2}$ & 0.000 & Sign \\
\hline & D3 & 99 & $4.56 \pm 2.016$ & -32.0 & 97 & $5.86 \pm 1.995$ & -13.4 & $\mathrm{dT}_{3}$ & 0.000 & $\underline{\text { Sign }}$ \\
\hline & D4 & 98 & $3.64 \pm 2.022$ & -45.8 & 96 & $5.11 \pm 2.051$ & -24.5 & $\mathrm{dT}_{3}$ & 0.000 & $\underline{\text { Sign }}$ \\
\hline & D5 & 95 & $2.86 \pm 1.916$ & -57.4 & 95 & $4.43 \pm 2.191$ & -34.6 & $\mathrm{dT}_{5}$ & 0.000 & Sign \\
\hline & D6 & 90 & $2.04 \pm 1.779$ & -69.6 & 89 & $3.94 \pm 1.979$ & -41.8 & $\mathrm{dT}_{6}$ & 0.000 & $\underline{\text { Sign }}$ \\
\hline & D7 & 87 & $1.45 \pm 1.468$ & -78.4 & 85 & $3.37 \pm 1.853$ & -50.2 & $\mathrm{dT}_{7}$ & 0.000 & Sign \\
\hline & D8 & 83 & $0.98 \pm 1.370$ & -85.4 & 80 & $2.81 \pm 1.801$ & -58.5 & $\mathrm{dT}_{8}$ & 0.000 & $\underline{\text { Sign }}$ \\
\hline & D9 & 83 & $0.47 \pm 0.980$ & -93.0 & 77 & $2.08 \pm 1.692$ & -69.3 & $\mathrm{dT}_{9}$ & 0.000 & $\underline{\text { Sign }}$ \\
\hline & D10 & 83 & $0.18 \pm 0.665$ & -97.3 & 77 & $1.48 \pm 1.498$ & -78.1 & $\mathrm{dT}_{10}$ & 0.000 & $\underline{\text { Sign }}$ \\
\hline \multirow{10}{*}{$\begin{array}{c}\text { Self- } \\
\text { assess } \\
\text { ment } \\
\text { diffic } \\
\text { ulty } \\
\text { swallo } \\
\text { wing }\end{array}$} & D1 & 100 & $6.39 \pm 2.006$ & & 100 & $6.39 \pm 2.049$ & & & - & - \\
\hline & D2 & 99 & $5.55 \pm 2.214$ & -13.1 & 98 & $6.02 \pm 2.082$ & -5.8 & $\mathrm{dT}_{2}$ & 0.000 & $\underline{\text { Sign }}$ \\
\hline & D3 & 99 & $4.36 \pm 2.169$ & -31.8 & 97 & $5.55 \pm 2.250$ & -13.1 & $\mathrm{dT}_{3}$ & 0.000 & $\underline{\text { Sign }}$ \\
\hline & D4 & 98 & $3.34 \pm 2.192$ & -47.7 & 96 & $4.72 \pm 2.209$ & -26.1 & $\mathrm{dT}_{3}$ & 0.000 & $\underline{\text { Sign }}$ \\
\hline & D5 & 95 & $2.61 \pm 2.054$ & -59.2 & 95 & $4.09 \pm 2.343$ & -36.0 & $\mathrm{dT}_{5}$ & 0.000 & $\underline{\text { Sign }}$ \\
\hline & D6 & 90 & $1.82 \pm 1.669$ & -71.5 & 89 & $3.55 \pm 2.094$ & -44.4 & $\mathrm{dT}_{6}$ & 0.000 & $\underline{\text { Sign }}$ \\
\hline & D7 & 87 & $1.21 \pm 1.542$ & -81.1 & 85 & $3.07 \pm 2.046$ & -52.0 & $\mathrm{dT}_{7}$ & 0.000 & $\underline{\text { Sign }}$ \\
\hline & D8 & 83 & $0.72 \pm 1.300$ & -88.7 & 80 & $2.54 \pm 1.935$ & -60.3 & $\mathrm{dT}_{8}$ & 0.000 & $\underline{\text { Sign }}$ \\
\hline & D9 & 83 & $0.31 \pm 0.896$ & -95.1 & 77 & $1.94 \pm 1.681$ & -69.6 & $\mathrm{dT}_{9}$ & 0.000 & $\underline{\text { Sign }}$ \\
\hline & D10 & 83 & $0.19 \pm 0.818$ & -97.0 & 77 & $1.43 \pm 1.517$ & -77.6 & $\mathrm{dT}_{10}$ & 0.000 & Sign \\
\hline
\end{tabular}


medRxiv preprint doi: https://doi.org/10.1101/2021.03.10.21253255; this version posted March 12, 2021. The copyright holder for this preprint (which was not certified by peer review) is the author/funder, who has granted medRxiv a license to display the preprint in

It is made available under a CC-BY 4.0 International license.

At the beginning of the study (Day 1), the results of the assessment performed by the patients were similar in both groups. Since initially the groups did not differ in the self-assessed severity of symptoms, individual differences dT1 = (Day 2-Day 1) were calculated. .... dT10 = (Day 10-Day 1) by each parameter. Starting from Day 2, a more pronounced regression of main complaints was observed in the treatment group (more than $13 \%$ ) compared to the control group (less than $6 \%)(\mathrm{p}>0.05)$.

A significantly more pronounced regression of main complaints was observed in the treatment group on all consecutive days of follow-up period till the end of the followup period ( $\mathrm{p}>0.05$ in all cases). In general, the results of patients' self-assessment of symptoms in dynamics correspond to the results of the physicians' assessment (statistically significant difference between the groups).

Improvement of local symptoms of acute tonsillitis and general well-being leads to a decrease in the amount of systemic non-steroidal anti-inflammatory drugs taken. The dynamics of NSAID administration was assessed (Table 5). The last drug administration date was taken into account.

Table 5.

The dynamics of systemic NSAID administration depending on the group.

\begin{tabular}{|l|c|c|c|c|c|c|c|c|c|c|}
\hline Day/Group & $\mathbf{1}$ & $\mathbf{2}$ & $\mathbf{3}$ & $\mathbf{4}$ & $\mathbf{5}$ & $\mathbf{6}$ & $\mathbf{7}$ & $\mathbf{8}$ & $\mathbf{9}$ & $\mathbf{1 0}$ \\
\hline $\begin{array}{c}\text { Treatment } \\
\text { group } \\
(\mathrm{n}=100)\end{array}$ & 70 & 55 & 25 & 6 & 2 & 1 & 0 & 0 & 0 & 0 \\
\cline { 2 - 13 } & $70.7 \%$ & $55.6 \%$ & $25.5 \%$ & $6.3 \%$ & $2.2 \%$ & $1.15 \%$ & $0.0 \%$ & $0.0 \%$ & $0.0 \%$ & $0.0 \%$ \\
\hline $\begin{array}{c}\text { Control } \\
\text { group } \\
(\mathrm{n}=100)\end{array}$ & 70 & 62 & 50 & 29 & 13 & 10 & 3 & 0 & 0 & 0 \\
\cline { 2 - 12 } & $70.7 \%$ & $63.9 \%$ & $52.1 \%$ & $30.5 \%$ & $14.6 \%$ & $11.8 \%$ & $3.8 \%$ & $0.0 \%$ & $0.0 \%$ & $0.0 \%$ \\
\hline $\begin{array}{l}\text { p-value } \\
\text { Conclusion* }\end{array}$ & 0.946 & -0.294 & 0.0003 & 0.0001 & 0.003 & 0.005 & 0.116 & 1.000 & 1.000 & 1.000 \\
\hline
\end{tabular}

There was a significant difference in NSAID administration between patients of the treatment and control groups starting from Day 3 of treatment ( $p>0.05)$. The duration of antipyretic administration by patients of the treatment group was 
medRxiv preprint doi: https://doi.org/10.1101/2021.03.10.21253255; this version posted March 12, 2021. The copyright holder for this preprint (which was not certified by peer review) is the author/funder, who has granted medRxiv a license to display the preprint in It is made available under a CC-BY 4.0 International license.

$2.36 \pm 1.649$ days, which is less than in the control group: $3.12 \pm 0.494$. The difference is significant $(\mathrm{p}=0.014)$.

The groups were compared according to the number of patients who received antibacterial drugs (Fig. 2).

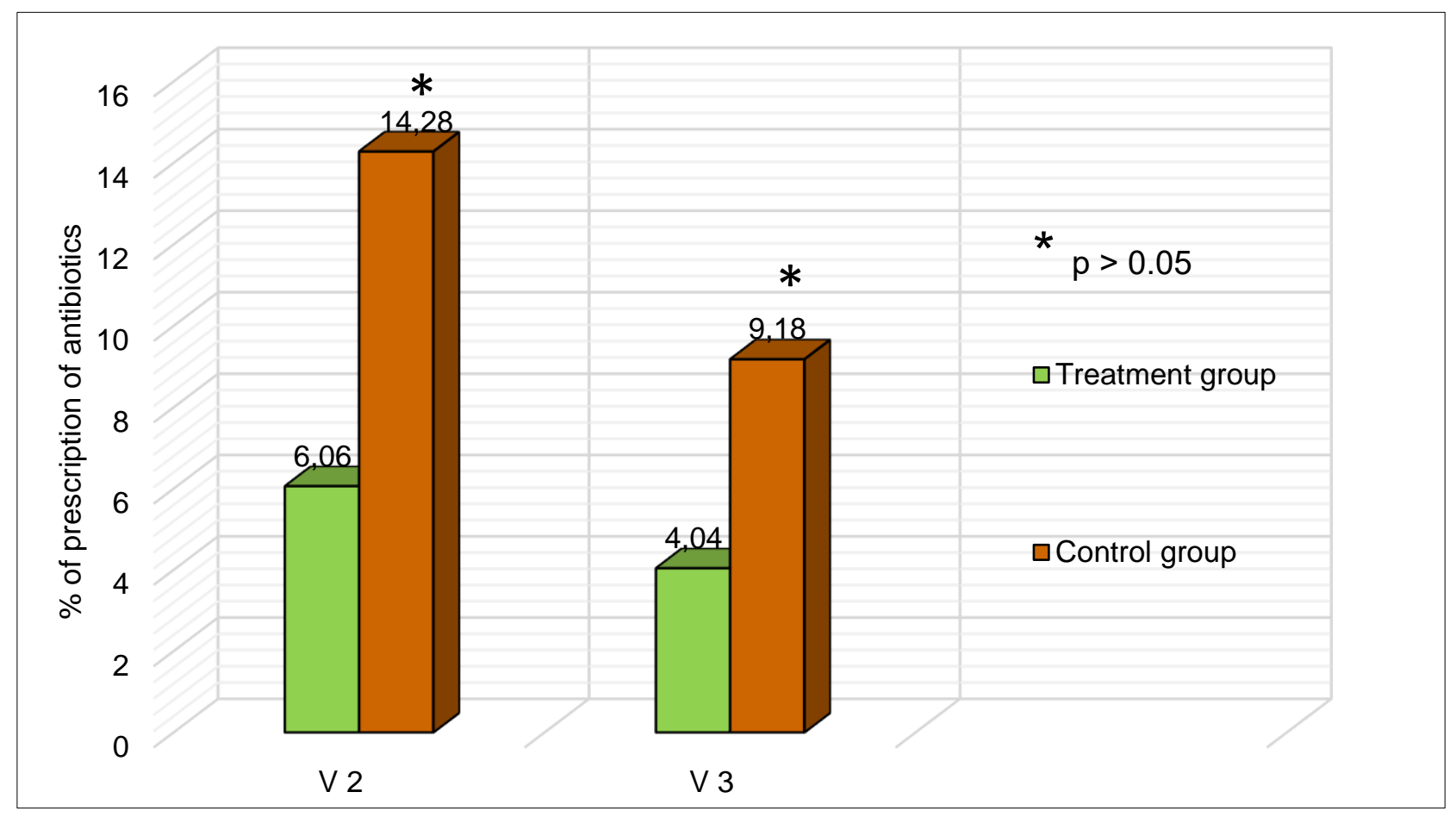

Figure 2. Antibiotic prescription in the groups

As can be seen from Figure 2, antibiotics were prescribed at V2 to $6(6.06 \%)$ patients in the treatment group and $14(14.28 \%)$ patients in the control group. Two days later (V3), antibiotics were additionally prescribed to $4(4.04 \%)$ patients in the treatment group and $9(9.18 \%)$ patients in the control group. Thus, in accordance with the technology of delayed prescription, antibiotic treatment was prescribed to 10 $(10.1 \%)$ patients in the treatment group and $23(23,46)$ patients in the control group. The difference between the groups was significant $(p=0.0223)$.

\subsection{Safety and tolerability}

An analysis of the tolerability assessment findings showed that the treatment was well tolerated or very well tolerated in all cases. In the course of treatment, no 
medRxiv preprint doi: $h t t p s: / / d o i . o r g / 10.1101 / 2021.03 .10 .21253255$; this version posted March 12, 2021. The copyright holder for this preprint (which was not certified by peer review) is the author/funder, who has granted medRxiv a license to display the preprint in

significant side effects, as well as streptococcus-associated complications requiring additional treatment or drug withdrawal, were registered in any patient.

\section{Discussion}

Acute bacterial tonsillitis occurs in immunocompetent children in $20-30 \%$ of cases [2]. Current guidelines recommend symptomatic agents (topical and systemic NSAIDs) for symptom relief, primarily sore throat. For antibiotic prescription, patients are stratified using the Centor-McIsaac Scale. When the condition is assessed in $>3$ points, immediate antibiotic prescription is recommended only if streptococcus is verified. In the absence of verification, antibiotics are prescribed using the technology of delayed prescription $[10,11]$. However, the frequency of antibacterial drug prescriptions in severe acute tonsillitis reaches $90 \%$ [5, 6]. In terms of using a delayed antibiotic strategy, initial treatment should be highly effective. Many researchers are of the opinion that with low confidence in the regression of tonsillitis symptoms during treatment, there is always a question about the antibiotic prescription both among physicians and the desire for antibiotic therapy among patients themselves or their parents [12]. According to the design, our study enrolled patients with diagnostic criteria for severe acute tonsillitis. The symptom severity according to the McIsaac Scale in the treatment group was 4.45, in the control group -4.41 points. It has been demonstrated that the use of the standardized phytoextract BNO 1030 in addition to standard symptomatic therapy for severe acute tonsillitis has proven therapeutic benefits. Patients in the treatment group demonstrated a clinically significant reduction in the symptom severity assessed by the physician as early as V2 ( $p>0.005)$. There were significant differences in the patient's self-assessment of general well-being, the severity of sore throat and difficulty swallowing according a 10-point scale starting as early as Day 2 (D2) of treatment $(\mathrm{p}>0.005)$. An important and interesting conclusion of the study is that due to a more pronounced regression of sore throat, as well as an improvement in general well-being, patients in the BNO 1030 group discontinued systemic antipyretics earlier. The duration of their administration was $2.36 \pm 1.649$ days 
medRxiv preprint doi: https://doi.org/10.1101/2021.03.10.21253255; this version posted March 12, 2021. The copyright holder for this preprint (which was not certified by peer review) is the author/funder, who has granted medRxiv a license to display the preprint in perpetuity.
It is made available under a CC-BY 4.0 International license.

compared to $3.12 \pm 0.494$ in the control group. The difference in the antipyretic administration was significant starting from Day 3 of treatment $(\mathrm{p}>0.05)$.

Thus, the patients of the treatment group showed a significant "therapeutic benefit" in comparison with the control group starting from Day 2 of treatment. As part of the technology of delayed prescription, this is very important since the decision to prescribe antibiotics is made after assessing the dynamics of symptom regression on Day 3-5 of treatment.

As known, it is difficult for a physician to adhere to the technology of complete refusal to prescribe antibiotics in acute tonsillitis, especially when assessing the condition according to the Centor-McIsaac Scale in three or more points. That is why the delayed prescription is considered in patients with severe tonsillitis. In our study, the technology of delayed antibiotic prescription was used in $23(23.46 \%)$ patients in the control group. The number of prescriptions corresponds to the average incidence of bacterial tonsillitis [2]. Antibiotic therapy was prescribed to $10(10.12 \%)$ patients of the treatment group ( $p>0.05$ ). Thus, an important conclusion of the study is that the use of BNO 1030 in patients with severe acute tonsillitis significantly reduces, by $43.7 \%$ or 2.3 -fold, the need for antibacterial therapy when using the technology of delayed antibiotic prescription.

At the same time, according to the literature, the delayed prescription tactics are not widespread and the frequency of antibacterial drug prescriptions in acute tonsillitis reaches up to $90 \%[5,6]$. According to the DESCARTE study, the difference in the level of immediate and delayed prescriptions in patients with a Centor score of $>3$ points is very modest, not more than $13 \%$, and not statistically significant [30]. The proven efficacy of BNO 1030 is an important argument to reduce the urge of physicians and patients to immediate antibiotic prescription.

The proven high efficacy of acute tonsillitis treatment in the treatment group in terms of severe regression of symptoms in the first two-three days will make it possible to more widely implement the delayed antibiotic prescription strategy and greatly reduce the number of irrational antibiotic prescriptions. 
medRxiv preprint doi: $h t t p s: / / d o i . o r g / 10.1101 / 2021.03 .10 .21253255$; this version posted March 12, 2021. The copyright holder for this preprint (which was not certified by peer review) is the author/funder, who has granted medRxiv a license to display the preprint in It is made available under a CC-BY 4.0 International license.

The efficacy of BNO 1030, shown in this study, is generally confirmed by the earlier study results in patients with acute non-bacterial tonsillitis [28]. When BNO 1030 was administered, a "therapeutic benefit" in four days was obtained on Day 10 of treatment compared to the control group. The strength of the present study is the symptom-based stratification of patients of $4-5$ points according to the McIsaac Scale, which corresponds to the concept of "severe acute tonsillitis". It is the diagnosis of severe tonsillitis that is the main reason for irrational antibiotic prescription. The groups of randomized patients, homogeneous in clinical manifestations, made it possible to draw reasonable conclusions on comparative treatment results. The "therapeutic benefit" at the time of the decision on the delayed antibiotic prescription $(\mathrm{V} 2, \mathrm{~V} 3)$ is more than two days in patients of the treatment group. This reflects a significant advantage in assessing the condition and rationale for prescribing antibiotics as part of the technology of delayed prescription.

The limitation of this study is the lack of placebo control. However, the comparison was carried out during treatment according to clinical recommendations, which provide for the mandatory prescription of symptomatic therapy only with the use of NSAIDs [2, 13, 14]. Consequently, all the differences in treatment results can be attributed to the clinical effects of BNO 1030.

\section{Conclusions}

It was shown that the additional use of the phytoneering drug BNO 1030 for the treatment of severe acute tonsillitis significantly reduces the clinical symptoms, improves the assessment of patients' general well-being and quality of life starting from Day 2 and reduces the use of NSAIDs from Day 3 of treatment. This makes it possible to reduce antibiotic prescriptions by $43.7 \%$ or 2.3 -fold as part of the technology of delayed prescription. The inclusion of the drug in the treatment regimen may be recommended for patients with severe acute tonsillitis.

The direction for future research is to study the efficacy of the drug as an adjunct to antibacterial therapy in patients with acute bacterial tonsillitis. 
medRxiv preprint doi: $h t t p s: / / d o i . o r g / 10.1101 / 2021.03 .10 .21253255$; this version posted March 12, 2021. The copyright holder for this preprint (which was not certified by peer review) is the author/funder, who has granted medRxiv a license to display the preprint in It is made available under a CC-BY 4.0 International license.

\section{References}

1. Shaikh N, Leonard E, Martin JM. Prevalence of streptococcal pharyngitis and streptococcal carriage in children: a meta-analysis. Pediatrics. 2010;126:e557-e564

2. S2k-Leitlinie 017/024:Therapie entzündlicher Erkrankungen der

Gaumenmandeln-Tonsillitis [Therapy of inflammatory diseases of the palatal tonsils

- Tonsillitis], Stand 08/2015.

http://www.awmf.org/uploads/tx_szleitlinien/0170241_S2k_Tonsillitis_Gaumenmand e ln_2015-08_01.pdf).

3. Bochner RE, Gangar M, Belamarich PF. A Clinical Approach to Tonsillitis, Tonsillar Hypertrophy, and Peritonsillar and Retropharyngeal Abscesses. Pediatr Rev. 2017 Feb;38(2):81-92. doi: 10.1542/pir.2016-0072.

4. K. Stelter. Tonsillitis and sore throat in children. GMS Curr. Top.

Otorhinolaryngol. Head. Neck Surg., 13 (2014), p. Doc07

http://www.egms.de/static/en/journals/cto/2014-13/cto000110.shtml

5. Spurling GK, Del Mar CB, Dooley L, Foxlee R, Farley R. Delayed antibiotic prescriptions for respiratory infections. Cochrane Database Syst Rev. 2017 Sep 7;9:CD004417. doi: 10.1002/14651858.CD004417.pub5.

6. Stephen D. Persell, Jason N. Doctor, Mark W. Friedberg, Daniella Meeker, Elisha Friesema, Andrew Cooper, Ajay Haryani, Dyanna L. Gregory, Craig R. Fox, Noah J. Goldstein and Jeffrey A. Linder Behavioral interventions to reduce inappropriate antibiotic prescribing: a randomized pilot trial. BMC Infectious DiseasesBMC series - open, inclusive and trusted201616:373 https://doi.org/10.1186/s12879-016-1715-8

7. Ónodi-Nagy K, Kinyó Á, Meszes A et al. Amoxicillin rash in patients with infectious mononucleosis: evidence of true drug sensitization. Allergy Asthma Clin Immunol 2015;11:1 10.1186/1710-1492-11-1 
medRxiv preprint doi: https://doi.org/10.1101/2021.03.10.21253255; this version posted March 12, 2021. The copyright holder for this preprint (which was not certified by peer review) is the author/funder, who has granted medRxiv a license to display the preprint in It is made available under a CC-BY 4.0 International license.

8. I. Roca, M. Akova, F. Baquero, J. Carlet, M. Cavaleri, S. Coenen, et al. The global threat of antimicrobial resistance: science for intervention New Microbes New Infect., 6 (2015), pp. 22-29

9. WHO global strategy to contain antimicrobial resistance http://www.who.int/drugresistance/WHO_Global_Strategy_pdf

10. John M. Eisenberg. Interventions To Improve Antibiotic Prescribing for Uncomplicated Acute Respiratory Tract Infections Comparative Effectiveness. Review Summary Guides for Clinicians [Internet]. Center for Clinical Decisions and Communications Science. Baylor College of Medicine, Houston, Texas Issued: April 6, 2016.

11. Little P1, Williamson I, Warner G, Gould C, Gantley M, Kinmonth AL. Open randomised trial of prescribing strategies in managing sore throat. BMJ. 1997 Mar 8;314(7082):722-7.

12. Van Driel ML, De Sutter A, Deveugele M, Peersman W, Butler CC, De Meyere M, De Maeseneer J, Christiaens T. Are sore throat patients who hope for antibiotics actually asking for pain relief? Ann Fam Med. 2006 Nov-Dec;4(6):494-9. https://www.ncbi.nlm.nih.gov/pubmed/17148626

13. Hay AD, Costelloe C, Redmond NM, Montgomery AA, Fletcher M, Hollinghurst S, Peters TJ. Paracetamol plus ibuprofen for the treatment of fever in children (PITCH): randomised controlled trial. BMJ. 2008;337:a1302. [PMC free article] [PubMed]

14. Hay AD, Redmond NM, Costelloe C, Montgomery AA, Fletcher M, Hollinghurst S, Peters TJ. Paracetamol and ibuprofen for the treatment of fever in children: the PITCH randomised controlled trial. Health Technol Assess. 2009 May;13(27):iii-iv, ix. doi: 10.3310/hta13270.

15. Sullivan JE, Farrar HC, Section on Clinical Pharmacology and Therapeutics, Committee on Drugs. Clinical report - Fever and antipyretic use in children.

Pediatrics. 2011;127:580-587 Version: 15 January 2020, JPID ... 16

16. Cannon JG. Perspective on fever: the basic science and conventional medicine. Complement Ther Med. 2013;21 Suppl 1:S54-60 
medRxiv preprint doi: https://doi.org/10.1101/2021.03.10.21253255; this version posted March 12, 2021. The copyright holder for this preprint (which was not certified by peer review) is the author/funder, who has granted medRxiv a license to display the preprint in perpetuity.
It is made available under a CC-BY 4.0 International license .

17. Carey JV. Literature review: should antipyretic therapies routinely be administered to patients with [corrected] fever? J Clin Nurs. 2010;19:2377-2393 18. Evans SS, Repasky EA, Fisher DT. Fever and the thermal regulation of immunity: the immune system feels the heat. Nat Rev Immunol. 2015;15:335-349 19. Kluger MJ, Kozak W, Conn CA, Leon LR, Soszynski D. The adaptive value of fever. Infect Dis Clin North Am. 1996;10:1-20

20. Aminoshariae A, Khan A. Acetaminophen: old drug, new issues. J Endod. $2015 ; 41: 588-593$

21. Beasley R, Clayton T, Crane J, et al. Association between paracetamol use in infancy and childhood, and risk of asthma, rhinoconjunctivitis, and eczema in children aged 6-7 years: analysis from Phase Three of the ISAAC programme. Lancet. 2008;372:1039-1048

22. Schillie SF, Shehab N, Thomas KE, Budnitz DS. Medication overdoses leading to emergency department visits among children. Am J Prev Med. 2009;37:181-187 23. S. Salatino, A. Gray Integrative management of pediatric tonsillopharyngitis: an international survey Complement. Ther. Clin. Pract., 22 (2016), pp. 29-32 Explore (NY). 2007 Nov-Dec;3(6):573-84.

24. Careddu D, Pettenazzo A. Pelargonium sidoides extract EPs 7630: a review of its clinical efficacy and safety for treating acute respiratory tract infections in children. International journal of general medicine. 2018;11:91-98

25. Pahl A. Imupret modulates the innate and adaptive immune system parameters in vitro. Planta Med. 2009;75:PJ200.

26. Hostanska K, Melzer J, Amon A, Saller R. Suppression of interleukin (IL)-8 and human beta defensin- 2 secretion in LPS- and/or IL-1 $\beta$-stimulated airway epithelial A549 cells by a herbal formulation against respiratory infections (BNO 1030). J Ethnopharmacol 2011;134:228-33.

27. Prokhorov EV, Tolstikova EA, Pedenko AV, Burbelo EN. Immunological resistance state and effectiveness of acute respiratory virus infection (ARVI) complications prophylaxis and treatment in children. ZdorovyeUkrainy 2004;3(88)http://www. health-ua.org/archives/health/560.html. 
medRxiv preprint doi: https://doi.org/10.1101/2021.03.10.21253255; this version posted March 12, 2021. The copyright holder for this preprint (which was not certified by peer review) is the author/funder, who has granted medRxiv a license to display the preprint in It is made available under a CC-BY 4.0 International license.

28. V.I. Popovych, I.V. Koshel, A.N. Malofiichuk, et al. A randomized, openlabel, multicenter, comparative study of therapeutic efficacy, safety and tolerability of BNO 1030 extract, containing Althea root, Cammomile flowers, horsetail herb, walnut leaves, yarrow herb, oak bark, dandelion herb in the treatment of acute nonbacterial tonsillitis in children aged 6 to 18 years. Yajot (2018), https://doi.org/10.1016/j.amjoto.2018.10.012 29. Popovych V. I., Koshel I. V. Treatment of acute tonsillitis from the perspective of evidence-based medicine. Analysis of modern research. Otorhinolaryngology. Eastern Europe. 2019, Volume 9, No 1, p. 199-213 30. Moore M, Stuart B, Hobbs R. et. all.Symptom response to antibiotic prescribing strategies in acute sore throat in adults: the DESCARTE prospective cohort study in UK general practice. British Journal of General Practice 2017; 67 (662): e634-e642. DOI: https://doi.org/10.3399/bjgp17X692321 